\title{
Vállalkozói képzés a 21. században a felsőoktatásban - lehetőségek, módszerek, jó gyakorlatok
}

\author{
G. ÁRVÁné VÁNYI ${ }^{1}$, J. KATONÁNÉ KovÁCS², T. GÁL ${ }^{3}$, P. PopoviCS ${ }^{4}$ \\ ${ }^{1}$ Debreceni Egyetem Gazdaságtudományi Kar, arvane.vanyi.georgina@econ.unideb.hu \\ 2Debreceni Egyetem Gazdaságtudományi Kar, katonane.kovacs.judit@econ.unideb.hu \\ ${ }^{3}$ Debreceni Egyetem Gazdaságtudományi Kar, galtimea@agr.unideb.hu \\ ${ }^{4}$ Debreceni Egyetem Gazdaságtudományi Kar, popovics.peter@econ.unideb.hu
}

Absztrakt. A 21. század kihívásai a felsőoktatást is elérték és sürgős megoldásokat igényelnek. Európában a felsőoktatási intézmények által kínált vállalkozói kurzusok, programok átlagosan 10 éves múltra tekintenek vissza. Miközben az üzleti képzések ezen ága folyamatosan a legitimációjáért küzd, tisztán látszik az, hogy amit kínál a végzett hallgatók számára, az egy fontos előny a munkaerőpiacon és a gazdasági életben. Ezen tanulmány célja, hogy válaszokat adjon a következő kérdésekre: Miért olyan fontos a vállalkozói képzés napjainkban? Milyen módszertant használnak leggyakrabban a vállalkozó képzésben? Milyen eredményeket tudnak felmutatni a felsőoktatásban múködő vállalkozói kurzusok? A kérdésekre a témához kapcsolódó legfrissebb szakirodalomból, esettanulmányokból és a Debreceni Egyetemen 2010 óta folyó Team Academy, csapatvállalkozói képzés alumni körében végzett primer kutatás eredményei alapján fogunk választ adni. A Team Academy Debrecen a Finnországban 1993 óta létező Tiimiakatemia oktatási módszert alkalmazza, amely egy innovatív oktatási módszertan. Kutatásunk eredményei alapján elmondható, hogy a vállalkozói készségek taníthatóságával kapcsolatos kihívásokra adható válaszok legfontosabb területei: a cselekvő tanulás, a motiváció, a közösségi és a csapatban tanulás, a coaching és a mentoring.

Abstract. Challenges of the 21st century require answers from higher education as well. In Europe, most of the entrepreneurship programmes on the higher education institutions are less than ten years old. Whilst business studies may battle for academic legitimacy, it has a clear advantage when it comes to graduate employability. The aim of this paper is to give answer to the following questions: why entrepreneurship education is important, what are the methods which are already used and what are the results of them. The answers to the questions are based on literature reviews, a case study and in-depth interviews with alumni carried out at the University of Debrecen, where since 2010 Team Academy Debrecen, a new education model from Finland is implemented. Tiimiakatemia education is an innovative Finnish model founded in 1993 by Johannes Partanen that develops team entrepreneurs. Based on the results some of the important elements of entrepreneurship teachability are: learning by doing, passion, learning in teams, coaching and mentoring.

\section{Bevezetés}

Ezen tanulmány szerzői a Debreceni Egyetem Vállalkozásfejlesztési Tanszékén dolgozó egyetemi oktatók, képzett coachok, akik többéves tapasztalattal rendelkeznek, hogyan lehet a hagyományos oktatási módszereket megújítani a vállalkozói képzésekben. 
A tanulmány bevezetőjében a 21. század kihívásairól lesz szó, alátámasztva a vállalkozásoktatásban az új, innovatív módszerek fontosságát és bemutatva az Európai Unió már megtett lépéseit ennek kommunikációjában és támogatásában. A cikk második részében a vállalkozásoktatás módszereiről és annak "taníthatósági dilemmájáról" szóló irodalmakat mutatjuk be, végül a Team Academy Debrecen alumni körében végzett primer kutatás eredményeit ismertetjük.

Marquardt [2011]szerint a 8 legfontosabb tényező, amely megváltoztatta az üzleti világot és szükségessé tette a szervezeti tanulást a 21. században:

1. globalizáció és a globális gazdaság,

2. technológia és Internet,

3. a munka világának radikális változása,

4. növekvő fogyasztói erő,

5. a tudás és a tanulás, mint szervezeti tőke fontosságának növekedése,

6. a munkavállalók várakozásainak megváltozott szerepe,

7. munkavégzés helyének diverzitása és mobilitása,

8. a gyors változás és a káosz.

Pink [2009] szerint ma a az „Agrárium korából”[farmerek], az „Ipari Korból”[gyári munkások] és az „Információ korából”[tudás munkások] elérkeztünk az „Gondolkodók Korához”.

Az információ és a kommunikáció létfontosságú szerepet játszik számtalan szolgáltatásban, ami elsődleges a személyközi kapcsolatok tekintetében is. A növekvő szolgáltatói szektor fejlett szociális és kommunikációs készségekkel rendelkező embereket, munkavállalókat igényel. Anderson [2012] arra hívta fel a figyelmet, hogy azok a társadalmak a nyertesek napjainkban, amelyek a közös alkotás, vagy a közösségi alapú fejlesztést preferálják.

Az Oivallus tanulmány, amely arról szól, hogy az oktatás hogyan tudja leghatékonyabban felkészíteni a hallgatókat a munka világára a 2020-as évekre, rámutat arra a tényre, hogy a jövőbeni projektekben nagyon különböző emberek fognak dolgozni [CFI, 2011]. Egy csapatnak és tagjainak nagyon erős alap kompetenciákkal és erős motivációval kell rendelkeznie majd, hogy meg tudjon küzdeni az ismeretlen szituációkkal.

Hálózatban dolgozni, tanulni egymástól és együttmúködni, mások ötleteiből is építkezni azok a készségek, amelyekkel elengedhetetlenek lesznek a sikerhez. Mindezek hiányában a különböző személyiségű szakértők nem tudnak együtt, csapatban dolgozni. Ezen készségek fejlesztése tehát elengedhetetlen.

Az UNESCO meghatározta a tanulás 4 pillérét, amelyek az oktatás átalakításának legalapvetőbb pilléreivé kell, hogy váljanak.

Ezek a következőt jelentik:

- A tudás tanulása. Az oktatásnak biztosítani kell azokat a kognitív/elméleti eszközöket, tudást, amelyek szükségesek a világ és komplexitása megértéséhez. Ezenkívül pedig szükségesek ahhoz, hogy mindez elegendő és adekvát alapot adjon a jövőbeni tanuláshoz. 
- A cselekvés tanulása.Biztosítani kell azoknak a készségeknek a fejlesztését, amelyek képessé teszik az egyéneket a hatékony részvételre a globális társadalomban és gazdasági életben.

- A létezés tanulása. Az oktatás feladata, hogy az egyénnek olyan önismereti és szociális készségek fejlesztését biztosítsa, amelyek segítik őt pszichológiailag és szociálisan valamint fizikailag "teljes" emberré válni.

- Az együtt létezés tanulása. Fontos, hogy az oktatás világítson rá az egyén számára az emberi jogokra, az egyéni belső értékekre, a demokratikus jogokra, az interkulturális megértés, tisztelet és béke fontosságára a társadalom minden szintjén, valamint az emberek közötti kapcsolatok és a harmónia fontosságára.

A hagyományos iskolai modelleken való túllépés kapcsán a legnagyobb kihívások az emberek érzelmeiben és a hiedelmeikben, értékeikben és feltételezéseikben gyökereznek. Az elérendő cél nem könnyű feladat: a reform modellnek szakmai elkötelezettséget, politikai akaratot és kulturális elköteleződést kell generálnia egy időben [Dede, 2011].

\section{Fiatalok a munkaerőpiacon napjainkban}

Napjaink Európájában a fiatalok számára nagyon nehéz feladat megtalálni a helyüket a munka világában, munkaerő-piaci részvételüknövelése politikai prioritássá vált. Jó példái enneka 2011-es "Több lehetőséget a fiataloknak" és a "Fiatalok foglalkoztatása" programcsomag, melyek az Európai Tanács 2013 áprilisi döntése alapján az "Ifjúsági Garanciaprogram" bevezetésében teljesedtek ki valamennyi Európai Uniós tagállamban.

A fiatalokvállalkozóvá válása magas szintű prioritássá vált az Európai Unióban az önfoglalkoztatás és a humán tőke fejlesztésből kifolyólag. Ezt támogatja a 2013-ban az Európai Bizottság által kiadott "Vállalkozás 2020 Akcióterv" kommunikációja is. A dokumentum konkrét intézkedéseket javasolt az európai vállalkozói potenciál fejlesztésére és a vállalkozói lét előtt álló akadályok leküzdésére [Eurofund, 2015].

Az Európai Bizottság valójában azt szeretné, hogy a vállalkozói attitűd mintegy viselkedési forma legyen a köztudatban jelen, amely támogatja az emberek mindennapi életét.

Az oktatás feladata ennek elérése érdekébenaz, hogy a fiatalok számára segítséget nyújtson a vállalkozói attitűdök fejlesztésében és fejlessze a készségeiket a következő területeken:

- kreativitás

- innovativitás

- kockázatmenedzsment

- project szemlélet

- példamutatás

- felelősségvállalás

- önállóság, autonómia

- célorientáltság. 
Ezt a folyamatot már általános iskolában érdemes elkezdeni [European Commission, 2004a], ami azt biztosítja, hogy a korán megszerzett tudás végigkíséri az embert egész élete során.

A 2013-as „Vállalkozás 2020 cselekvési terv” előtt a vállalkozói attitűdök korai fejlesztésétmár a 2004ben elfogadott,,Vállalkozásakcióterv" program is támogatta [European Commission, 2004b].

"A vállalkozás 2020 cselekvési terv" határozott céljai:

1. közös fellépéssel növelni Európa vállalkozói potenciálját,

2. megszüntetni a meglévő akadályokat és

3. forradalmasítani a vállalkozói kultúrát Európában.

A program célja, hogy olyan támogató környezetet teremtsen, amelyben sokkal könnyebb új vállalkozásokat létrehozni, valamint a már meglévőknek növekedni és fejlődni. A terv a következő 3 pillérre épül:

1. A vállalkozói ismeretek oktatása és képzés a vállalkozások alapításának és növekedésének támogatására.

2. A keretfeltételek javítása a vállalkozók számára.

3. A vállalkozói kultúra dinamizmusának fokozása: a vállalkozók új generációinak kinevelése [European Commission, 2013].

A Tagállamok többek között felkérést kaptak arra, hogy:

- 2015 vége előtt biztosítsák azt, hogy a vállalkozói készség, mint kulcs kompetencia helyet kapjon a képzésekben mind az alapfokú, a középfokú és a felsőfokú oktatásban, valamint a szakképzésben és a felnőttképzésben.

- Teremtsék meg a lehetőséget a fiatalok számára, hogy legalább 1 gyakorlati, vállalkozói tapasztalattal hagyják el az oktatási rendszert, ez lehet egy mini vállalkozás vezetése, felelősségvállalás egy projektért egy vállalat számára, vagy egy szociális projekt [European Commission, 2013].

\section{3. "A taníthatóség dilemmája"}

Az üzleti témák tantárgyaira tipikusan jellemző vagy a multidiszciplinaritás, vagy a diszciplínába sorolás nehézsége. Az üzleti iskolák és az üzleti tudományos kurzusok hosszú idők óta küzdenek az akadémiai legitimációjukért, talán pontosan a fentiekből kifolyólag.

A munkáltatók és általánosságban a munkaerőpiac részéről egyre inkább nő a végzés után azonnal alkalmazható és használható tudás iránti igény, ami egyértelműen a különböző tudások és diszciplínák kombinálását és integrálását igényli.

Mialatt az üzleti tudományok folyamatosan küzdenek az akadémiai legitimációjukért, a munkaerőpiacon a gyakorlatorientált és kompetencia fókuszú üzleti diplomák értéke folyamatosan nő[Hatt, 2015]. 
Az elmúlt évtizedekben tanúi lehettünk annak, ahogy a vállalkozás, mint tudományos terület, diszciplína folyamatosan növekszik, fejlődik és helyet talál magának az oktatás minden szintjén különböző kurzusokkal és programokkal[Hisrich, 2003; Solomon et al., 2002].

Szintén az elmúlt évtizedekben vált érzékelhetővé, hogy az egyetemek már nem csak az első két missziójuk beteljesítésére fókuszálnak: ami az oktatás és a kutatás, hanem egyértelműen figyelembe veszik múködésük során a gazdasági és kulturális környezetükben zajló folyamatokat is és önmagukat ennek részeként értelmezik [Etzkowitz, 2000; Vorley \& Nelles, 2008 in European Commission 2008b].

Általánosságban a harmadik misszió a következő feladatokban jelenik meg az egyetemek és azok külső környezete vonatkozásában végzett tevékenységei között: technológiai transzfer és innováció, folyamatos képzés és szociális elkötelezettség.

A harmadik misszió dimenziója nagyon közel áll az oktatáshoz és tréninghez.

A folyamatos oktatás/élethosszig tartó tanulás kifejezés a következőket jelenti: "minden tanulási tevékenység az élet során a tudás, a kompetenciák és a készségek fejlesztését szolgálja az egyéni, az állampolgári, a szociális és/vagy alkalmazotti perspektívákat is figyelembe véve" [European Commission, 2001].

A hagyományos oktatási sémák, módszertanok az üzleti és a gazdasági témák vonatkozásában elsősorban oktatásorientáltak, leginkább az elméleti és speciális tudásra fókuszálva arra készítik a hallgatókat, hogy nagyvállalatoknál dolgozzanak a későbbiekben.

Napjainkban ez a helyzet változni látszik, a felsőoktatási intézmények új funkciókat kezdenek ellátni, erősítve ezzel az egyetemek harmadik missziójának küldetését [Gibb, 1996; Johannisson et al., 1998; Etzkowitz et al., 2000].

Az elmúlt 20 évben, a Nyugat-Európai egyetemek jelentős előrelépést mutatnak a vállalkozói kurzusok tekintetében, különös tekintettel a Skandináv [e.g. Johannisson, 1991; Rasmussen and Sørheim, 2006] és a német nyelvű országokra [Klandt et al., 2008].

Az elmúlt időszakban Kelet-Európa [e.g. Mitra and Matlay, 2004; Boyle, 2007], Ázsia [Dana, 2001; Rae, 1997] és Latin-Amerika [Tiffin, 2004] egyetemein is megfigyelhető a vállalkozói képzések iránti elkötelezettség növekedése.

A vállalkozói képzések, az általános szakirodalmak és a gyakorlati tapasztalatok vizsgálatai jelentős heterogenitást mutatnak a filozófia, a célok, a tartalom, a módszertanok és a hatékonyság tekintetében. Haase és Lautenschlager [2011] szerint a vállalkozói képzés a csecsemőkorát éli.

Nem vitatható, hogy a vállalkozással kapcsolatos elméletek könnyen taníthatók hagyományos módszerekkel, nem utolsó sorban azért is, mivel eléggé közel állnak a hagyományos menedzsmenthez. Ezzel ellentétben, a vállalkozói készségek, amelyek tapasztalati úton tanulhatók igazán hatékonyan, már sokkal nehezebben adaptálhatók és fejleszthetők a hagyományos oktatás keretei között, pedig ez az, amitől igazán hatékonnyá válik egy vállalkozói kurzus.

Simon Sinek Arany kör elméletét felhasználva - "Miért? - Hogyan? - Mit?" - Haase és Lautenschlager [2011] 3 fő kompetenciát és képességet határozott meg, amelyek esszenciálisak a vállalkozók számára: 
1. „Tudni, hogy mit?”: Tények a vállalkozások alapításával és menedzsmentjével kapcsolatban.

2. „Tudni, hogy hogyan?”: McMullan és Long [1987] szerint a vállalkozás oktatásnak feltétlen tartalmaznia kell készségfejlesztést az alábbi területeken: tárgyalás, vezetés, kreatív gondolkodás és technológiai innovációs készségek. Ronstadt [1990] ezenkívül még külön hangsúlyoz olyan készségeket, mint a kreativitás, a bizonytalanság tűrés, lehetőségek azonosítása, stratégiai látásmód, megállapodás és hálózatosodás, kapcsolatépítés. Az előbbiekben említetteken kívül, Rae [1997] a kommunikációs készségeket hangsúlyozza elsősorban a meggyőzésre fókuszálva, a továbbiakban pedig a kritikai gondolkodást, a problémamegoldást és az időmenedzsment készségeket. Ronstadt [1987] szerint a vállalkozói kurzusok kialakítása során figyelemmel kell lenni arra, hogy növelje az akadályokkal szembeni éberséget már a vállalkozói karrier megindításától, valamint, hogy amennyire lehetséges felkészülten, megoldásokkal "várják" ezeket az akadályokat. Gibb [2007] a motivációt említi első helyen a vállalkozói értékek között, mely nagyon szoros relációban áll a vállalkozói gondolkodással és érzésekkel, cselekedetekkel.

3. „Tudni, hogy miért?”: Johannison [1991] szerint ennek alapja a vállalkozói értékek, a célok, az önbizalom és a kitartás.

Rae és Carswell [2001] elismeri, hogy az üzleti és menedzsment funkcionális tudásanyag, az üzleti terv [„Mit?”] relatív könnyen tanítható hagyományos módszerekkel, ezzel szemben például a kreativitás és az innovativitás [„Hogyan?” és „Miért?” komponensek] egyáltalán nem.

Haase és Lautenschlager [2011] vállalkozói képzések pedagógiai hatékonyságát mérő empirikus kutatása elsősorban a "Miért" és kismértékben a "Hogyan" kérdéskörök hatásának mérésére irányult, nem utolsó sorban a működőképesség miatt.

Gyakorlatilag, szinte egyáltalán nem biztosított a hagyományos vállalkozói kurzusok, programok esetében a személyiség alapú készségek fejlesztése, úgy, mint a proaktivitás, a vezetői készségek, a kockázatkezelési hajlandóság, az éberség és a teljesítmény iránti késztetés[„Hogyan?” és „Miért?” komponensek].

Mindezek áttekintése után, konzekvenciaként merült fel a "Oktathatósági dilemma” a vállalkozástan oktatása és a vállalkozói kurzusok kapcsán. Egyrészről a vállalkozói “Hogyan?” megléte elengedhetetlen a sikeres vállalkozásalapításhoz, és a képzésben való megjelenése az, ami valójában megkülönbözteti a vállalkozói képzéseket a hagyományos menedzsment kurzusoktól.

Másrészről, ezek a készségek nem, vagy nehezen taníthatók, sokkal inkább megtapasztalás útján tanulhatók. Más szavakkal: akármennyi vállalkozói képesítést is képesek a vállalkozói képzések, kurzusok, iskolák biztosítani, valamennyi legnagyobb kihívása abban áll, hogyan közvetítse a vállalkozás, a vállalkozói lét központi értékeit.

Blenker et al. [2008] szerint alapvetően vitatható, hogy az oktatási rendszer a jelenlegi formájában képes-e egyáltalán fejleszteni a hallgatók motivációját, kompetenciáit és készségeit a vállalkozói képzésekben. Megegyeztek abban, hogy jelenleg az egyetemek számára fejlesztendő terület: a szükséges módszertan, a pedagógiai folyamatok és a keretek meghatározása, kialakítása. 
A cselekvő és a tapasztalati tanulás tûnik a megfelelő módszernek arra, hogy a vállalkozói "Hogyan" adaptálhatóvá váljék a hallgatók számára. Ezzel várhatóan növekedik a pedagógiai hatékonyság, valamint a hallgatók megtapasztalják a vállalkozói lét, tevékenység különböző dimenzióit.

A vállalkozói képzéseket úgy célszerű kialakítani, hogy azok minél közelebb legyenek a valósághoz, olyan versenykörnyezetet teremteni, mint amiben a "valódi" vállalkozók is tevékenykednek [Carayannis et at., 2003; Hindle, 2002]. Smith et. al [2006] gyakorlatilag "valódi" vállalkozókkal való együttműködést, közös tevékenységeket és közösségi tanulótereket, környezetet javasol. David Birch szerint ösztönözni kell a vállalkozásokat is arra, hogy vegyenek részt gyakornoki programokban. Ez igazi tapasztalást jelenthet a hallgatók számára. [Aronsson, 2004.]Szerencsésnek mondható, hogy ma a felsőoktatásban az üzleti alapszakokon valamennyi hallgató számára kötelező a gyakornoki programban való részvétel.

Haase és Lautenschlager [2011] a vállalkozást oktató szerepének megváltoztatását is javasolta. Tanári szerepe mellett és sokszor a helyett fontos, hogy képes legyenhelyt állni akár facilitátorként és menedzserként, mentorként vagy coachként, attól függően, hogy mikor melyikre van leginkább szükség. Többek között működése során fontosabb, hogy "valódi” vállalkozásokkal, vállalkozókkal szervezzen tapasztalatcseréket a hallgatók számára, mint hogy tartson egy elméleti előadást.

Összegezve, a vállalkozói kurzusok számára fontos követelmény, hogy a hagyományos oktatás helyett tapasztalati tanulási élményekhez kell juttatni a hallgatókat. Ez az egyetlen út a szükséges "Hogyan?” komponens tanulhatóságához [Haase és Lautenschlager, 2011].

\section{A team academy Debrecen esettanulmánya}

Európában jellemzően kevesebb, mint 10 éves a vállalkozói kurzusok zöme. Ugyanez a szám az USAban 40-50 év [Internet 1]. Ezen esettanulmányban szereplő képzés alapját képző finn üzleti képzési modell: a Tiimiakatemia több mint 20 éves.

\section{A Tiimiakatemia ${ }$ modell bemutatása}

Az OECD és a finn kormány, valamint az Európai Unió által is már több alkalommal kitüntetett Tiimiakatemia Finnországban a JAMK University of Applied Sciences egyetemen múködik. Johannes Partanen alapította 1993-ban. A módszer az üzlet és az oktatás különlegesen innovatív kombinációja.

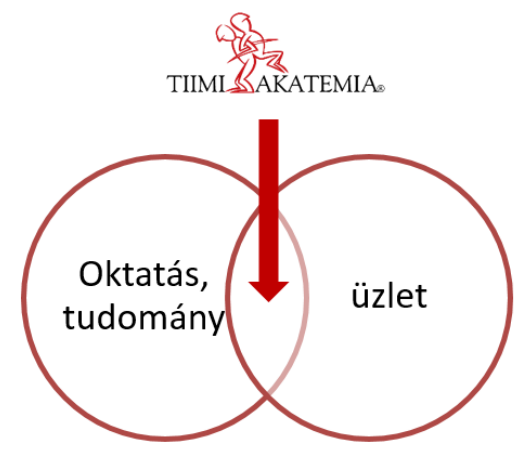

1. ábra: A Tiimiakatemia helye az oktatásban

(Forrás: saját szerkesztés) 
A módszer létrejöttével kapcsolatban Partanen [2012] a következőket írta: “Megszületett az a gondolatom, hogy az embereknek körben kellene ülniük. Azt láttam, hogy dialógus indul el az emberek között, mint Szókratész idején."

A Tiimiakatemia-ban tanulók csapatban működnek, független gazdasági formát, szövetkezetet hoznak létre és alapszakos közgazdászként diplomáznak. Valódi projektjeik vannak, amelyeken keresztül megtalálják önmagukat, érdeklődésüket és mindeközben finanszírozzák a cégük működését. A projektek és a vállalkozás gyakorlatilag keretet, tanulási környezetet biztosítanak ahhoz, hogy megtanulják hogyan is kell vállalkozni. A Tiimiakatemia-nak nincs jogi kontroljaa vállalkozások fölött,csak a coachingot biztosítja 1. táblázat] a tanulási folyamathoz.[Internet 2].

\begin{tabular}{|l|c|}
\hline Hagyományos képzés & Tiimiakatemia \\
\cline { 2 - 3 } hallgatók & csapat vállalkozók \\
\cline { 2 - 3 } osztályterem & közösségi irodatér \\
\cline { 2 - 3 } oktatás & tanulás \\
\hline oktatók & coachok \\
\hline $\begin{array}{l}\text { szimulációk, } \\
\text { esettanulmányok }\end{array}$ & valódi projektek, \\
\cline { 2 - 3 } & üzleti tevékenység \\
\hline szabályok & önszabályozás \\
\hline
\end{tabular}

1. táblázat: A hagyományos egyetemi képzés és a Tiimiakatemia módszertan közötti föbb különbségek

(Forrás: saját szerkesztés Internet 2. alapján)

A Partanen által kidolgozott 4 kerék meghajtásos tanulási elmélet [Toivanen, 2014] tartalmazza a fóbb módszertani elemeket úgy, mint az elmélet és a könyvek, a tanulási szerződés, a dialógus a tréningeken, és a vevőkkel való aktív kapcsolattartás a projektek révén. A módszer legfontosabb alapjai a cselekvő és a csapatban való tanulás.

A projektek lehetőséget adnak a vállalkozó hallgatóknak, hogy a megismert elméletet közvetlenül ültessék át a gyakorlatba, és ezzel egy időben teret ad számukra, hogy reflektáljanak a tapasztalataikra, támogatva ezzel a saját és társaik tanulási folyamatát.

A hallgatók könyveket olvasnak, és az abban megismert elméletekkel támogatják a tevékenységeiket. Azt olvassák, amire valóban szükségük van az üzleti tevékenységeikhez. A csapatok dialógust alkalmaznak a tudásmegosztáshoz és a közös gondolkodáshoz. A dialógus alkalmazásának célja, hogy továbblépjen az egyén a személyes értelmezésén és megértésén, megismerje, és saját fejlődéséhez felhasználja mások tapasztalatait is, ugyanakkor hozzájáruljon társai fejlődéséhez.

A dialógus során az emberek megfigyelőivé válnak a saját gondolkodásuknak, ezáltal igen fejlett önreflexióra lesznek képesek. Valószínűleg ez és a valódi tapasztalatok teremtik meg az alapot ahhoz, 
hogy aTiimiakatemia-n végzettek 42\%-a elindítja a saját vállalkozását az oklevél megszerzésétől számított 3 éven belül [Internet 2].

Lehtonen [2013] a következőképpen írja le a Tiimiakatemia szerkezetét, rendszerét. A rendszer alapjai a következő háromszög elemei: a Tiimiakatemia, a csapattag és a csapat. Középpontban a csapattag áll, mivel mindennek az alapja a vállalkozni vágyó, bátor és inspirált elsőéves csapatvállalkozó tanuló. Ő csapat szerződés által kapcsolódik, ami lefekteti a közös szabályokat, célkitűzéseket és célokat, melyeket a csapat együtt hoz létre.

A tanulók élete a Tiimiakatemiában annak vezérlő elvei mentén zajlik, ami tartalmazza a célkitűzéseket, a közös értékrendet, a víziót, missziót és a célokat. A tanulók, akik a vezérlő elvek mentén működnek, tartják életben a Tiimiakatemia élő és inspiráló márkáját, valamint a saját vállalkozásuk márkáját.

Elkötelezettségük a csapathoz és a Tiimiakatemiához, energikus munkájuk és közös tanulásuk a vevővel - ami szintén egy tiszteletteljes interakció -együtt hozzák létre a tanulás egy magasabb szintjét.

Mindezek gyümölcsöző üzleti eredményeket, jól működő hálózatokat és hatékony tanulást eredményeznek, amelyek az alapját képezik a csapatvállalkozás fejlődésének. Manapság a Tiimiakatemia módszertan márkaként terjed a világon és építi folyamatosan a csapatvállalkozás eszméjét.

Finnországban Jyvaskyla-n kívül még

- $\quad$ Turkuban [Yrkeshögskolan Novia, Turku Nunnankatu 4, 20100 Turku, FINLAND www.novia.fi; University of Applied Science, Turku Bachelor of Hospitality Management - program Lemminkäisenkatu 30, 20520 Turku, FINLAND www.turkuamk.fi ],

- $\quad$ Tampere-ben [Proakatemia, Tampere Väinö Linnan aukio 15, 33210 Tampere, FINLAND www.proakatemia.fi ],

- Saimaa-ban [University of Applied Science, Saimaa Bachelor of Engineering - program Pohjolankatu 23, 53100 Lappeenranta, FINLAND www.saimia.fi ],

- $\quad$ Lahti-ban [University of Applied Science, Lahti Faculty of Social and Health Care - program Hoitajankatu 3, 15850 Lahti, FINLAND www.lamk.fi ],

Mikkeli-ben [University of Applied Science, Mikkeli Bachelor of Hospitality Management program Savonniemenkatu 6, 57100 Savonlinna, FINLAND www.mamk.fi ]

is zajlik Tiimiakatemia@ módszertant alkalmazó felsőoktatási alapszaki üzleti képzés.

A különleges vállalkozásfejlesztés fókuszú alapszakképzés a finn példa alapján, 2008 óta működik a spanyolországi Mondragon University-n is. A spanyol rendszerben a képzés elnevezése „Leadership, Entrepreneurship and Innovation Course - LEINN" néven várja az érdeklődő, vállalkozni vágyó hallgatókat [http://mondragonteamacademy.com/]. A Mondragon University szervezésében több spanyolországi campuson is folyik ez a speciális képzés, úgy, mint Onati-ban, Irunban, Madridban, 
Barcelonában és Bilbaoban. Ezen kívül a Hollandiában Haarlemből indulva már Amszterdamban is elérhető.

Nagy-Britanniában 2013 ősze óta már 6 egyetemen indult a Tiimiakatemia@C módszertant alkalmazó képzés

- a University of Northumbria Newcastle Business School-ban [www.newcastlebusinessschool.co.uk/ ],

- $\quad$ a Falmouth University-n [http://www.falmouth.ac.uk/business-entrepreneurship ]

- $\quad$ a Bristol Business School-ban [http://courses.uwe.ac.uk/N191/ ],

- a Londonban található University of Westminster-ben a Westminster Business School-ban [www.westminster.ac.uk/schools/business ],

- a Brighton Aldridge Community Academy-ben [http://www.baca-uk.org.uk/EandB/TeamAcademy/ ] és a

- Lincoln Bishop Grossetteste University-n

[http://www.bishopg.ac.uk/study/ug/business/Pages/default.aspx ].

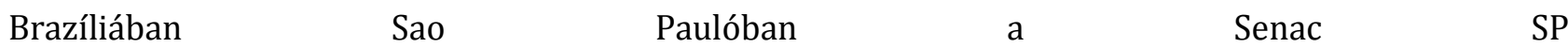

[http://www.sp.senac.br/jsp/default.jsp?newsID=a13156.htm\&testeira=1063 ] és a Banco Santander Brazil együttműködésében folynak az előkészületek, hogy a hallgatók számára alapszaki szinten elérhetővé váljon a Tiimiakatemia / Team Academy módszertan az üzleti képzésekben.

Franciaországban 2010 óta működik Strasbourgban az Ecole De Management Business School-ban a Tiimiakatemia elvein nyugvó vállalkozásfejlesztési kurzus [http://www.emstrasbourg.eu/_en/index.php].

\section{Tiimiakatemia módszertan a Debreceni Egyetemen - a Team Academy Debrecen}

A Team Academy Debrecen a Debreceni Egyetem Gazdaságtudományi Karán 2010-ben kezdte meg működését. A Kereskedelem és Marketing, a Pénzügy és Számvitel és a Turizmus és Vendéglátás alapszakon tanuló hallgatók az 5. szemeszterük kezdetén csatlakozhatnak a képzéshez. A módszertan, ahogyan azt korábban bemutattuk a "cselekvő tanulás" elvére épül. A hallgatók rendszerint Kft-t alakítanak a képzés keretein belül a Cégbíróságon bejegyezve. Kisebb csoportokban dolgoznak különböző projekteken. A csapatvállalkozók valódi projekteket bonyolítanak le az üzleti életben, ehhez a vállalkozásukat mintegy keretként alkalmazva.

A partnerek meg- és felkereséséért, a velük való tárgyalások megszervezéséért és lebonyolításáért, a szerződések megírásáért és a munkák elvégzéséért is maguk vállalnak teljes felelősséget. A csapatvállalkozó diákok heti 2 alkalommal 5 órás tréningeken vesznek részt, aminek célja a csapat működésének figyelemmel kísérése, és ha kell beavatkozás abba. Ezeken a tréningeken fokozottan figyelnek arra, hogy a dialógust, mint a tanuló szervezetek egyik alappillérét és eszközét folyamatosan alkalmazzák és gyakorolják. Ezek a tréningek az úgynevezett team coach által szervezettek és facilitáltak. A coach kérdésekkel és a dialógus irányításával dolgozik. Időnként előfordul, hogy a csapattagok [vállalkozó hallgatók] saját maguk számára is rendeznek egy-egy brainstorming alkalmat, 
hogy hirtelen felbukkant problémák esetén megoldást találjanak, vagy egy-egy elméleti témában prezentációt tartsanak egymásnak, ilyen módon gyakorolják az egymástól tanulást. A tréningeken dolgozzák fel az olvasott könyveket is, amelyekről a csapattagok reflexiós esszét is írnak. A módszertan az elmélet gyakorlatba való átültetését helyezi a középpontba, melyet a különböző elemek jól támogatnak. Mindemellett a gyakorlati tapasztalataikat is folyamatosan összevetik az elméletből tanultakkal.

A módszer alapját a Nonaka-Takeuchi [1995] tudásteremtés elmélete adja. A modellben szereplő lépések [externalizáció, szocializáció, kombináció és internalizáció] körforgást alkotnak, szerencsés esetben azonban nem egyszerű ismétlődésről, hanem emelkedő spirálról beszélhetünk: mások számára hasznosíthatóvá tett tudásunk kombinálódik további információkkal, majd új tudásként beépül agyunkba, és ismét átadásra vár. Eközben - ideális esetben - egyre többet tud minden érintett, röviden: tanulunk. Egy-egy vállalaton belül megszámlálhatatlanul sok, egymással átfedésben lévő tudásspirál azonosítható [Szakály, 2012].

\section{Az alumni körében végzett felmérés eredményei}

A Team Academy Debrecen alumni hallgatói körében mélyinterjú módszerrel végeztünk primer kutatást. A hallgatók 11 nyílt kérdésre adtak választ. Az első 4 kérdés a képzéshez való csatlakozás időpontjához és az alapszakukhoz kapcsolódott. Vizsgáltuk azt is, hogy milyen szintű képzésben végeztek a Team Academy képzéssel párhuzamosan. Az ezt követő kérdések arra irányultak, hogy mennyi ideig tartott mire állást találtak, és vizsgáltuk azt is, hogy milyen típusú az a szervezet ahol most dolgoznak.

Az utolsó kérdéskör arra irányult, hogy milyen készségekben fejlődtek és mit tartanak a legfontosabbnak abból, amit megtanultak a Team Academyben, melyek azok az elemek a képzésben amiket fejlesztenének az eredményesség érdekében.

A mélyinterjúkat 2015 június-július időszakban készítettük el összesen 35 fő végzett hallgató közreműködésével.

A megkérdezettek közül a kezdés évét tekintve 14 fő 2010-ben csatlakozott a Team Academy képzésbe elsőként. 9 fő kezdett 2011-ben, 2 fő 2012-ben és 10 fő 2013-ban kezdte el tanulmányait a finn oktatási módszer szerint.

A végzettek átlagosan közel 6 félévet [5,59] töltöttek a Team Academy Debrecenben.

A Team Academy-n végzett hallgatók többsége [35 főből 25 fő, azaz 71\%] kereskedelem és marketing alapszakos volt, 2-2 fó pénzügy-számviteles és turizmus-vendéglátás szakos, 5 fő [7\%] pedig már mesterszakos volt a képzés megkezdésekor.

A végzettek közel fele [48,5\%; 17 fő] fejezte be a Team Academy-s képzést alapszakon, 12 fő alap- és mesterszakot, 5 fő pedig csak mesterszakot végzett.

A végzést követően azonnal saját vállalkozást indított 5 fő [14\%], 1 fő pedig a családi vállalkozását folytatta. A végzést követően 5 fő tanult tovább [14\%] és 4 fő volt, aki a végzést követően még nem helyezkedett el. A többi végzett hallgató közül 3 fő állami intézménynél kezdett el dolgozni, 
egynegyedük [9 fő] hazai tulajdonú kis- és középvállalkozásnál és 8 fő [23\%] multinacionális cégnél. Összegzésként elmondható, hogy a Team Academy-ben végzett hallgatók 89\%-a dolgozik, amelyből közel egyötöde [19\%] saját vállalkozásában.

A megkérdezettek álláskereséssel töltött idejét tekintve megállapítható, hogy átlagban 4,11 hónap alatt helyezkedtek el.

$\mathrm{Az}$ alumni tagok körében azt is felmértük, hogy mennyi volt az első nettó fizetésük a végzés után. A kitöltők 14\%-ának az első nettó fizetése 100 ezer Ft alatt volt, míg 37\%-uknak [13 fő] 101 és 150 ezer Ft között volt ez az összeg. A megkérdezettek több mint egyötödének [22\%] 151 és 200 ezer Ft között volt az első fizetése és csupán 2 fő volt az, aki már több mint 201 ezer Ft-ot vihetett haza. Megállapítható, hogy a frissen végzettek közel egyharmadának az első fizetése már átlagos, illetve átlag feletti volt, hiszen ma a KSH szerinti átlagjövedelem $159.308 \mathrm{Ft}$.

A következő kérdés arra irányult, hogy a képzés során melyek voltak azok a tapasztalatok, amelyeket hasznosítani tudnak most a munkájukban. A megkérdezettek 40\%-a kiemelte a csapatmunkát, a csapatjátékot és az együttműködést, amelynek napi szinten hasznát veszik. A másodikként kiemelt elsajátított készség a hatékony kommunikáció volt. Hasonló arányban említették meg a válaszadók a vállalkozások múködtetésével kapcsolatban szerzett gyakorlati tapasztalatot, illetve ehhez kapcsolódóan a komplex vállalkozói szemléletet, gondolkodást, melyet egy hagyományos képzésben véleményük szerint nem sajátíthattak volna el.

A kitöltők hangsúlyozták még a gyakorlati angoltudás megszerzését, mivel volt, akit kifejezetten emiatt vettek fel a munkahelyére. Szintén sokan fontosnak tartották a képzés során elsajátított emberismeretet, illetve önismeretet is, mivel az önreflexión keresztül a hallgatók sokkal tisztább képet látnak magukról, mint mások a saját korosztályukból, így tudatosan tudják magukat fejleszteni. Az egymásnak adott visszajelzésekből a hallgatók önbizalma is nőtt, vagy a helyére került. Ezekből következik az önállóság és kezdeményezőkészség elsajátítása is, mivel megtanulják, hogy hogyan tudnak reális célokat maguk elé kitűzni és a kitűzött céljaikat el is érni. Ezzel kapcsolatban pedig még a kitartás fontosságát is sokan megtanulták.

Többen említették a konfliktuskezelést is, mivel a képzés során a hallgatók megtanulják konfliktusaikat asszertíven kezelni, amelyet a hétköznapi életbe is átültetnek. A Team Academy képzésében elsajátított tapasztalatok közül megemlítették még többek között nyitottságot, hogy hogyan lehet másokat motiválni, illetve hogyan adják el saját magukat.

A válaszadók közül többen is megemlítették azt, hogy megtanulták, hogy a problémákat kihívásként kezeljék, mely által más szemlélettel kezelik ezeket a szituációkat. Illetve azt is elsajátították, hogy sokszor a megoldást saját magukban kell keresni.

Voltak olyan válaszadók is, akik kiemelték, hogy számukra nagyon hasznosak voltak a könyvek, amelyeket el kellett olvasniuk a képzés alatt.

A leghasznosabbnak ítélt értékek között a volt hallgatók megemlítették, hogy számukra nagyon nagy kincs az, hogy felismerték a kapcsolati tőke fontosságát, valamint a saját vállalkozást indítók itt jöttek rá, hogy a vállalkozói lét nekik való. Az egyik leghasznosabb dolognak tartották többen is, hogy a képzésen keresztül megtudták, hogy mire lehetnek képesek, mivel sok feladatban le tudták tesztelni a 
képességeiket. Többen említették a nemzetközi tapasztalatokat, illetve az elsajátított angoltudást is, mivel a Team Academy nemzetközi hálózata biztosítja, hogy gyakorolják a nyelvtudásukat és folyamatosan új embereket ismerjenek meg.

Volt olyan válaszadó is, aki a leghasznosabb magával vitt értéknek azt tartja, hogy megtanulta mennyi mindent nem tud még. Többen kiemelték a tréningeken való részvétellel elsajátított szakmai ismereteket, amelyeknek szintén hasznát veszik.

Összességében a hallgatók pozitív véleménnyel rendelkeznek azzal kapcsolatban, hogy mennyi mindent tanultak a képzés alatt, amelyet folyamatosan hasznosítanak.

Az utolsó kérdés arra vonatkozott, hogy mi az, amit javítanának a képzésen a jövő generációi számára. A válaszadók véleménye egyöntetű volt abban a tekintetben, hogy jobban korlátozni kellene a felvettek körét, illetve alaposabban kellene tesztelni a jelentkezőket, hogy mennyire motiváltak. Egyes vélemények szerint a csoportok méretét is csökkenteni kellene, illetve a felvetteknek önállóan kellene csoportot alakítaniuk.

A megkérdezettek szerint nagyobb hangsúlyt kellene fektetni a szankciókra azokkal szemben, akik nem tartják be az előre lefektetett szabályokat vagy nem dolgoznak megfelelően. Egyes vélemények szerint a képzést be kellene árazni, és ha valaki elhagyja a képzést, akkor ki kellene fizetnie a tréningek árát, így növelhető lenne az elkötelezettség, hogy tényleg próbáljanak aktívak lenni és értékelni azt, amit a Team Academy-ben kapnak.

Többen is említették, hogy csak angol nyelven kellene tartani a tréningeket, mivel azok a leghasznosabbak.

Sokan arra fektetnék a hangsúlyt, hogy legyenek olyan mentorok a coachokon kívül, akik végigkísérik egy-egy csapat életét, projekteket biztosítanak és ellenőrzik a kivitelezést. Ezek a mentorok az üzleti életből érkeznének. A végzettek szerint egy-egy csapat esetében több projekten kellene dolgozni, és a gyakorlati félévet nem a Team Academy-s cégben töltenék, hanem külső cégnél, amely által új impulzusokat és projektötleteket is kaphatnának.

A végzettek szerint sokkal kevesebb „hagyományos” órai kötelezettségnek kellene lenni ahhoz, hogy megfelelő módon a vállalkozással tudjanak foglalkozni.

A hallgatók szerint az egyetemnek pénzügyi segítséget kellene nyújtani a vállalkozás alapításához, mivel az is problémát okozhat a vállalkozás elindításánál vagy, hogy valaki részt vegyen ebben a képzésben.

\section{5. Összegzés, konklúzió}

A szerzők tapasztalatai és az esettanulmány eredményei azt mutatják, hogya több mint 20 éves tapasztalattal rendelkező Tiimiakatemia oktatási modell alkalmas választ jelenthet a "Taníthatósági Dilemmára". Ez azt jelenti, hogy a kreativitás és az innovativitás [a "Hogyan" tudása és a "Miért" tudása összetevők] is fejleszthetők a módszer segítségével. A módszertan ezt támogató elemei a cselekvő tanulás, a csoportban tanulás és coaching. A vállalkozás tapasztalati úton tanulható, a csapatvállalkozó tanulók tanulmányaik alatt arra koncentrálnak, amiben igazán hisznek, ezáltal igazán motiváltak és 
elkötelezettek lesznek. A Team Academy résztvevői értik, hogy vállalkozónak lenni azt jelenti, hogy ha van egy probléma, akkor arra egész biztosan van megoldás is és a kihívásokat le lehet győzni.[Hat, 2015]

A kvalitatív kutatás értékelése alapján megállapítható, hogy a leghasznosabb tanulás és tapasztalat a hallgatók számára a csoportban való tanulás, a csapatmunka, az együttműködési készségek elsajátítása volt. Ezeket napi szinten tudják hasznosítani.

Haase és Lautenschlager [2011] javaslataival összecsengve - a vállalkozást oktatók szerepenék változtatásával kapcsolatban - a Tiimiakatemia team coach igen összetett munkát végez.

Ez az összetett szerepkör leginkább az üzleti életben agilis módszertannal dolgozó coachokra jellemző.

Az agilis coach feladatai a következők:

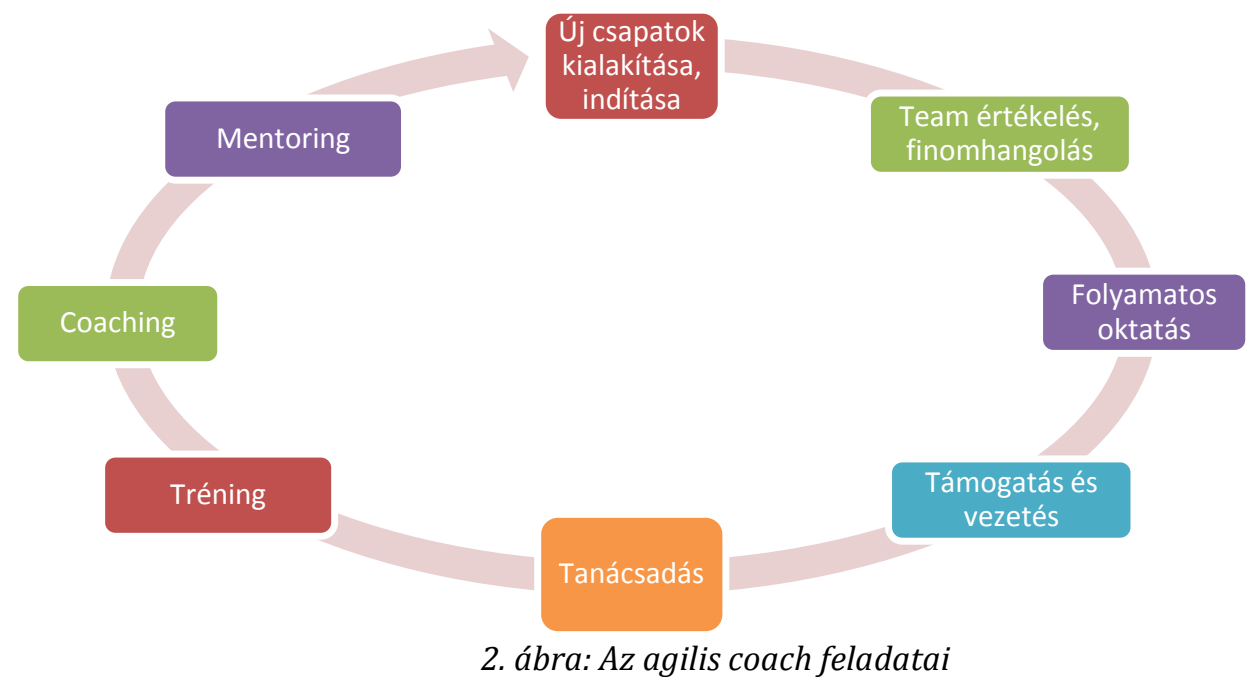

(Forrás: Davies és Sedley, 2009 alapján saját szerkesztés)

Jelen tanulmány eredményei összhangban állnak az Európai Bizottság [McCoshan, 2010] kutatásával is, mely szerint a vállalkozói képzés pozitív hatása az álláskeresésre és az elhelyezkedésre a munkatapasztalaton és a kreativitáson alapul.

A vállalkozói képzésekbe való beruházás egyike a legmagasabb megtérüléssel kecsegtető beruházásnak Európa tekintetében. Függetlenül attól, hogy folytatják vagy sem üzleti, vagy társadalmi vállalkozások alapítását és működtetését, a fiatalok, akik részesülnek a vállalkozói képzésben mindenképpen fejlesztik az üzleti tudásukat. Olyan alapvető készségeik fejlődnek, mint a kreativitás, a példamutatás, a kitartás, a csapatmunka, a kockázatmenedzselés és a felelősségvállalás.

Ez az a vállalkozói gondolkodásmód, amely segít a vállalkozóknak abban, hogyan váljon az ötletből valóság, valós cselekedeteken keresztül tevékenység. Jelentősége van az önfoglalkoztatás növelésében is, valamint a munkanélküliség csökkentésében [European Commision, 2013].

A tanulmány reményeink szerint segíti Európában ezen oktatási módszerek elterjedését. 


\section{Hivatkozások}

[1] C. Anderson (2012), Makers: The New Industrial Revolution, London: Random House

[2] M. Aronsson (2004), Education matters-but does entrepreneurship education? An interview with David Birch, Academy of Management Learning and Education, 3[3], 289292.

[3] P. Blenker, P. Dreisler, H. M. Faergemann, J. Kjeldsen (2008), A framework for developing entrepreneurship education in a university context, International Journal of Entrepreneurship and Small Business, 5[1], 45-63. doi:10.1504/IJESB.2008.015953.[2008]

[4] T. J. Boyle (2007), A new model of entrepreneurship education: implications for Central and Eastern European universities, Industry and Higher Education, 21, 9-19.

[5] E. G. Carayannis, D. Evans, M. Hanson (2003), A cross-cultural learning strategy for entrepreneurship education: outline of key concepts and lessons learned from a comparative study of entrepreneurship students in France and the US, Technovation, 23[9], 757-771. doi:10.1016/ S0166-4972[02]00030-5.

[6] CFI (2011), Oviallus: Final report, Helsinki: Confederation of Finnish Industries

[7] C. Dede (2011), 21st Century Education Requires Lifewide learning, Harvard Business Review https://hbr.org/2011/03/21st-century-education-require

[8] L. P. Dana (2001), The education and training of entrepreneurs in Asia, Education + Training, 43[8/9], 405-416. doi:10.1108/EUM0000000006486

[9] R. Davies, L. Sedley (2009), Agile Coaching

[10] European Commission (2001), Making a European Area of Lifelong Learning a reality, European Commission, COM, 678 final, Brussels

[11] European Commission (2008b), Needs and constraints analysis of the three dimensions of third mission activities. Lifelong Learning Program, Grant Agreement Number: 20083599/001-001. http://www.e3mproject.eu/docs/Three-dim-third-mission-act.pdf, letöltés dátuma: 2015. július 14.

[12] H. Etzkowitz, et. al (2000), The Future of the University and the University of the Future: Evolution from Ivory Tower to Entrepreneurial Paradigm, Research Policy, 29, 313-330.

[13] H. Etzkowitz, A. Webster, C. Gebhardt, B. R. C. Terra (2000), The future of the university and the university of the future: evolution of ivory tower to entrepreneurial paradigm, Research Policy, 29[2], 313-330. doi:10.1016/S0048-7333[99]00069-4.

[14] Eurofound (2015), Youth entrepreneurship in Europe: Values, attitudes, policies, Publications Office of the European Union, Luxembourg. doi:10.2806/806644 
[15] European Commission (2004a), Making Progress in promoting entrepreneurial attitudes and skills through Primary and Secondary education, Final Report http://europa.eu.int/comm/enterprise/entrepreneurship/support_measures/training_ed ucation/doc/entrepreneurship_education_final_en.pdf, Letöltés dátuma: 2015. június

[16] European Commission (2004b), Entrepreneurship Action Planhttp://europa.eu.int/comm/enterprise/entrepreneurship/action_plan.htm, Letöltés dátuma: 2015. június

[17] European Commission (2012), Communication from the commission to the European Parliament, the Council, the European Economic and Social Committee and the Committee of the Regions Entrepreneurship 2020 Action Plan, Reigniting the entrepreneurial spirit in Europe, Brussels, 9.1.2013 COM, 795 final [2013]

[18] A. A. Gibb (1996), Entrepreneurship and small business management: can we afford to neglect them in the twenty-first century business school?, British Journal of Management, 7[4], 309-321. doi:10.1111/ j.1467-8551.1996.tb00121.x.

[19] A. A. Gibb (2007), Entrepreneurship: unique solutions for unique environments. is it possible to achieve this with the existing paradigm?, International Journal of Entrepreneurship Education, 5[1], 93-142.

[20] H. Haase, A. Lautenschläger (2011), The 'Teachability Dilemma' of entrepreneurship, International Entrepreneurship Management Journal, 7:145-162 DOI: 10.1007/s11365010-0150-3 [2011]

[21] L. Hat (2015), Staff perspectives of threshold concepts in the context of an undergraduate entrepreneurial business degree programme. Developmental paper, British Academy of Management, Portsmouth, September 2015[2015]

[22] K. Hindle (2002), A grounded theory for teaching entrepreneurship using simulation games, Simulation \& Gaming, 33[2], 236-241. doi:10.1177/1046878102332012.

[23] R. D. Hisrich (2003), A model for effective entrepreneurship education and research, In K. Walterscheid [Ed.], Entrepreneurship in Forschung und Lehre: Festschrift für Klaus Anderseck [pp. 241-253]. Frankfurt/Main: Peter Lang.

[24] Internet 1: Top 25 Colleges for Entrepreneurship for 2015 [Graduate Programs], http://www.entrepreneur.com/slideshow/237323Letöltés dátuma: 2015. június

[25] Internet 2: Tiimiakatemia in a nutshell, http://tiimiakatemia.fi/en/tiimiakatemia/tiimiakatemia-nutshell/Letöltés dátuma: 2015. június

[26] B. Johannisson (1991), University training for entrepreneurship: Swedish approaches, Entrepreneurship \& Regional Development, 3[1], 67-82. doi:10.1080/08985629100000005. 
[27] B. Johannisson, H. Handström, J. Rosenberg (1998), University training for entrepreneurship: an action frame of reference, European Journal of Engineering Education, 23[4], 477-496. [1998]

[28] H. Klandt, L. T. Koch, J. Schmude, U. Knaup (2008), FGF-report 2008 entrepreneurship

[29] T. Lehtonen (2013), Tiimiakatemia - How to Grow into Teampreneur, JAMK University of Applied Sciences ISBN 978-951-830-290-5

[30] M. J. Marquardt (2011), Building the Learning Organization. Achieving Strategic Advantage through a Commitment to Learning, BostonMA: Nicholas Brealey

[31] A. McCoshan (2010), Towards Greater Cooperation and Coherence in Entrepreneurship Education, http://ec.europa.eu/enterprise/policies/sme/promotingentrepreneurship/education-training-entrepreneurship/reflectionpanels/files/entr_education_panel_en.pdf, Letöltés dátuma: 2015. június

[32] J. Mitra, H. Matlay (2004), Entrepreneurial and vocational education and training: lessons from Eastern and Central Europe, Industry and Higher Education, 18[1], 53-61.

[33] I. Nonaka, H. Takeuchi (1995), The knowledge creating company: how Japanese companies create the dynamics of innovation, New York: Oxford University Press, p. 284, ISBN 978-019-509269-1

[34] J. Partanen (2012), The Team Coach's Best Tools, Partus ISBN 978-952-67208-9-0

[35] D. H. Pink (2009), DRiVE: The Surprising Truth About What Motivates Us, New York: Riverhead Books, Professuren an \line deutschsprachigen Hochschulen: Ausrichtung, Organisation und Vernetzung. Bonn: FGF e. V. [2009]

[36] D. Rae (1997), Teaching entrepreneurship in Asia: impact of a pedagogical innovation, Entrepreneurship, Innovation, and Change, 6[3], 193-227.

[37] D. Rae, M. Carswell (2001), Towards a conceptual understanding of entrepreneurial learning, Journal of Small Business and Enterprise Development, 8[2], 150-158. doi:10.1108/EUM0000000006816.

[38] E. A. Rasmussen, R. Sørheim (2006), Action-based entrepreneurship education, Technovation, 26[2], 185-194.

[39] R. Ronstadt (1987), The educated entrepreneurs: a new era of entrepreneurial education is beginning, American Journal of Small Business, 11[4], 37-53.

[40] R. Ronstadt (1990), The educated entrepreneurs: a new era of entrepreneurial education is beginning, In C. A. Kent [Ed.], Entrepreneurship education: Current developments, future directions [pp. 69-88]. New York: Quorum Books

[41] A. J. Smith, L. A. Collins, P. D. Hannon (2006), Embedding new entrepreneurship programmes in UK higher education institutions: challenges and considerations, Education + Training, 48, 555-567. doi:10.1108/00400910610710001. 
[42] G. T. Solomon, K. M. Weaver, L. W. Fernald (1994), A historical examination of small business management and entrepreneurship pedagogy, Simulation \& Gaming, 25[3], 338352. doi:10.1177/ 1046878194253003.

[43] T. Szakály (2012), Tudásmenedzsment alapstratégiák: rövid összefoglalás, E-conom. Online tudományos folyóirat. 2012. I/1. 77-84. pp.

[44] P. Szirmai (2012), Az innovációra nevelés innovatív eszközei. Ifjúság - Vállalkozás Vállalkozásoktatás, Az Ifjúsági Vállalkozásoktatási Múhely zárókonferenciájának előadásai. Szerkesztette: Szirmai Péter. A könyv a TÁMOP-4.2.1/B-09/1/KMR-2010-0005 program, „A tudás alapú gazdaság Magyarországon, az innovációs szemlélet erősödésének és a K+F teljesítmények növelésének feltételei” alprojekt támogatásával készült. ISBN 978-963339-030-6. AULA Kiadó Kft. Corvinus Egyetem, Budapest

[45] P. Szirmai, K. Csapó (2006), Gyakorlati vállalkozásoktatás. Diákvállalkozások támogatása a Budapesti Corvinus Egyetemen, Új Pedagógai Szemle. 56. évf. 4. sz. 2006. áprilishttp://epa.oszk.hu/00000/00035/00102/2006-04-lk-Tobbek-Gyarkorlati.html, letöltés dátuma: 2014. január 6.

[46] S. Tiffin (2004), Entrepreneurship in Latin America: Perspectives on education and innovation, New York: Praeger

[47] H. Toivanen (2014), Friend Leadership, A Visual Inspiration Book, TEKES PELLERVO and JAMK University of Applied Sciences ISBN 978-952-93-4223-5

[48] UNESCO: Education. The four pillars of learning, http://www.unesco.org/new/en/education/networks/global-networks/aspnet/aboutus/strategy/the-four-pillars-of-learning/

[49] T. Vorley, J. Nelles, J.[Re] (2008), Conceptualising the Academy: Institutional Development of and beyond the Third Mission, Higher Education Management and Policy, 20 [3], 119-135. 